\title{
The Development Strategy of Jayapura Port with SWOT Analysis towards Isolated, Outermost, Lagging, and Border areas of Indonesia (T3P)
}

\author{
Willem Thobias Fofid ${ }^{1}$, Sutrisno Anggoro ${ }^{2}$ dan Wisnu Handoko ${ }^{3}$ \\ ${ }^{1}$ Master Program in Coastal Resource Management, Faculty of Fisheries and Marine Sciences, \\ Diponegoro University, Indonesia \\ ${ }^{2}$ Department of Aquaculture, Faculty of Fisheries and Marine Sciences, Diponegoro University, \\ Indonesia \\ ${ }^{3}$ Directorate General of Sea Transportation, Ministry of Transportation Republic of Indonesia, \\ Indonesia
}

\begin{abstract}
This article aims to analyze the policy strategies implemented for the commercial shipping development of the Apo Dock in Jayapura port to improve port performance towards strengthening the sea highway program. Apo Dock as a shipping commercial in Jayapura port has weaknesses as identified by the observation and the study of primary data. These weaknesses have resulted in price disparities for the Papua province as port functions well as a logistical hub. Based on the Strengthen-

Received:

January 1, 2019

\section{Accepted:}

July 16, 2019

\section{Corresponding Author:}

wilthooo@yahoo.co.id

Weakness-Opportunity-Threats (SWOT) analysis results, it was concluded that the Apo Dock performance as the Jayapura Port Commercial Route was in quota I with a position $(0.83 ; 1.44)$. The strategy used by Jayapura port to develop commercial shipping to be more efficient in accordance with its function as the strength-opportunity $(\mathrm{SO})$ strategy. The SO strategy strengthens the commercial shipping function as a support base for the economic development centers and a government supporter in MP3EI, the commercial port facilities and infrastructure development were established in order to support all port activities and efficiency, and develop hinterland areas to maximize the busy and crowded commercial shipping hub.
\end{abstract}

Keywords: Commercial Shipping; Apo Dock; SWOT Analysis.

\section{Introduction}

Indonesia as the largest archipelagic country in the world has very wide territorial waters (more than $67 \%$ are waters), the existence of which has been recognized under the International Law Provisions of the Sea Convention. The United Nations Convention on the Law of the Sea (UNCLOS 1982) puts the total sea area of the Unitary State of Indonesia Republic at 6,315,222 square kilometers $\left(\mathrm{km}^{2}\right)$ (Sea area throughout the world: 361 million $\mathrm{km}^{2}$ ), consisting of $282,583 \mathrm{Km}^{2}$ ( $80 \%$ of water) territorial sea area and $20 \%$ land, with national sea/inland area and 3,092,085 $\mathrm{km}^{2}$ archipelago waters, with 2,936,345 $\mathrm{km}^{2}$ Exclusive Economic Zone (ZEE), 99,093 $\mathrm{km}^{2}$ coastline length of the Indonesian archipelago, and has more than 17,504 islands stretching among large islands such as Sumatra, Java, Kalimantan, Sulawesi, Nusa Tenggara, Maluku and Papua. Moreover, there are $26,095.15 \mathrm{~km}^{2}$ extensive coral reefs and $36,164.45 \mathrm{~km}^{2}$ of mangrove areas, and approximately 13,466 islands (Diposaptono and Subandono 2015). Consequently, it needs an integrated and proportional shipping system in order to meet the national and regional economic demands as a maritime country, secure its borders and strengthen national sovereignty. However, sea transportation always has been the main issue in connecting all regions in the archipelago. Sea transportation is the most effective and efficient in connecting lagging and disadvantaged islands, now called Isolated, Outermost, Lagging and Border areas (T3P). 
In the economic field, commodities can be marketed quickly and smoothly if supported by the adequate shipping and ports. This requires an organized shipping and port planning system, equipped with facilities. Therefore, the cargo flow from ship to port can be well distributed. The focus area for the Indonesian ports' development is the T3P areas in supporting connectivity. The development of exclusive shipping systems in T3P areas, for example commercial shipping and port development planning in Jayapura, Papua Province, located in the eastern part of Indonesia.

The port is a place to move goods from one place to another by sea transportation. The process starts at the loading port and ends at the destination port. In general, the port function can be mentioned as a meeting place (interface), a gateway, an industrial entity, and a meeting place for various forms of transportation modes (Triatmodjo 2010). Jayapura has a port located on the right Strait of the City, named Jayapura Port. The Jayapura Port is operated by PT. Pelabuhan Indonesia IV as stated in Government Regulation No. 59 of 1991, thus of Jayapura Port's position or existence as mentioned in the Decree of Home Affairs and Transportation Minister No. 194 B in 1996 and Transportation Ministry Decree Number 69 of 1996 concerning the Jayapura Port Aquatic Environment (DLKP) Regional Boundaries and the Jayapura Port Area Work Environment Area (DLKR), due to the Papua province's vast territory, Papua Island and other islands around Jayapura (Rutz and Coull 1996). Therefore, it urgently needs a shipping system to serve the district and coastal areas which have the potential goods and cargo flows, such as the commercial shipping development in the Jayapura port.

Commercial shipping is a shipping activity carried out to connect undeveloped isolated areas with other developed or advanced regions. Commercial shipping is also given to other modes of transportation regions such as inadequate land and air transportation. Commercial shipping is established to connect commercially unprofitable areas to be served by the sea operators, river, lake or ferry transportation activities (PP No. 20 of 2010 article 70). The commercial shipping development in Indonesia based on the Shipping Law and Government Regulation on water transportation. In the latest rules, commercial shipping is regulated in the Government Regulation No. 20 of 2010 concerning Transportation in the waters. Especially for underdeveloped areas and/or isolated areas for sea transportation, waters, lakes, and crossings, the government provides the commercial shipping modes. Apo Dock is a pioneering commercial shipping routes and other domestic shipping vessels, it is a former of Dutch Indies government colonial legacy, still used in commercial shipping up to present even though the conditions are not feasible since it is only 346.5 $\mathrm{m}^{2}$.

The low flow of ship and commercial cargo that visits in the Jayapura Port is caused by the commercial presence and unfit commercial vessels with the existing cargo types and port facilities. The unsuitable docks at Apo become one of the main issues, therefore the commercial shipping impact of vessels which was operating in the Jayapura port cannot maximize the existing cargo spaces, this certainly has an impact on the goods accumulation, moreover a ship operational burden is not comparable to the voyage trip cost by route liners, resulting in an empty cargo space on commercial ships serving in Jayapura port after loading and going to the next port. Therefore, load accumulation was frequently occurred in warehouse, container depots, and goods storage or at ports. Thus, it will influence the good accumulation in the Eastern part of Indonesia, especially in Papua, is certainly very inversely proportional to the situation in the western part of Indonesia. A slow infrastructure cycle has triggered the high cost of commodities and impacted to the economy (Ministry of Transportation 2018).

Nawacita program which has been initiated by Indonesian Government declares Indonesia as the world's maritime axis (Nainggolan 2015). As a consequence, Regional Government of Papua Province and Jayapura develops the commercial shipping in Jayapura port and expected to have a positive impact on the development of Jayapura. Hopefully, the benchmark success of the program charge flow will reduce price disparities and prices in all corners of Indonesia, especially in the eastern part of Indonesia (Saragi et al. 2018).

Based on the Logistic Performance Index (LPI) score, Indonesia's sea transportation sector connectivity in 2014 is still much lower than Thailand and Malaysia. The challenge is the 
government implementation programs in the logistics sector. Therefore, infrastructure is a key factor in improving the supply chains. Based on the sea transportation connectivity index, the Eastern Indonesia Region connectivity index value is lagging far behind Jakarta, thus the development equality becomes an urgent issue (Bapennas 2015). Ports revitalization, including commercial shipping is necessary to improve the situation and the connectivity index of sea transportation in the Eastern Region. In the context of revitalizing commercial shipping ports, an integrated policy strategy needs to be established, which is connected to overcome the problems as well as future threats.

Internal and external information regarding commercial shipping has been utilized and analyzed in qualitative model's strategy formulation, therefore a strategy formulation can be provided as input and for the authorities' consideration in order to develop commercial shipping. The formulation of the commercial shipping development policy strategy focused on using qualitative models, such as the Internal Factors Analysis Summary (IFAS) matrix, External Factors Analysis Summary (EFAS) matrix, and matrix Strengths Weakness Opportunities Threats (SWOT) as the request information needed.

\section{Method}

In this study, the data were obtained from the results of primary and secondary data collection. Primary data is obtained by distributing questionnaires to the port service users and stakeholders in Jayapura Port. Secondary data collection is obtained from the literature and from port masters and port authority class II, Jayapura. The data obtained are used to analyze the strategic plan for developing the Apo Dock as a commercial shipping hub.

\section{The Apo Dock as Commercial Shipping Hub}

The Apo Dock is a dock intended for commercial ships, as legally stated in Home Affairs Minister SKB and Transportation Minister No. 194 B/KM 69 dated November 26, 1996. The large of Apo Dock is $346.5 \mathrm{~m}^{2}, 33 \mathrm{~m}$ long. The dock floor elevation is +3.2 meters LWS with carrying capacity of 1 ton $/ \mathrm{m}^{2}$, pond mooring $3,200 \mathrm{~m}^{2}$ in large, and the pool dept is about -6 to -7 meters LWS.

The general cargo services performance on commercial shipping has increased in demand for freight forwarding, this was in line with the commercial shipping vessels operation in the Jayapura Port, although there is frequently a decrease since the ship operation are very limited and often delays due to damaged road access for loading and unloading. The decrease around $5.9 \%$ in 2016 and in 2017 decline around $1.7 \%$. Loading and unloading service also decrease significantly in 2018 around $54 \%$, very narrow and limited operating area also there are no temporary terminals and warehouse facilities in the dock area cause this decrease.

The Apo Dock was built in 1960 in the days of the Dutch East Indies government had cracked conditions and the access to damaged roads coupled with a very narrow area only had an area approximately $346.5 \mathrm{~m}^{2}$, preventing supporting facilities such as forklifts from operating to maximum capacity and the passenger and warehouse terminals existence and passengers transit space (embarkation/ debarkation) must be immediately built and developed.

\section{Results of the SWOT Analysis}

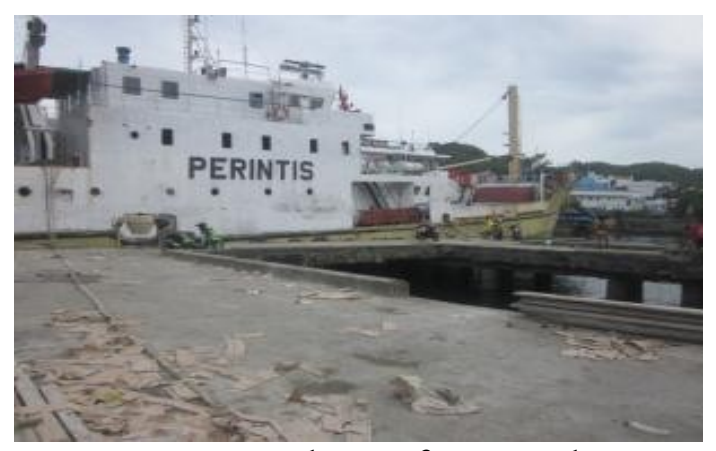

Figure 1. Condition of Apo Dock

Researcher's Documentation, 2018

SWOT analysis deals with the internal process analysis and the external environment with the identifying internal forces aim in order to take advantage of the external opportunities and avoid the 
external threats while overcoming internal weaknesses. This method was introduced by Albert Humphrey, who led a research project at Stanford University in the 1960s and 1970s last century (Wang, 2007). The SWOT method is used to analyze Strengths, Weaknesses, Opportunities, and Threats.

From the internal factor analysis, the commercial shipping results development strategy using the SWOT analysis are as follows that is indicated into the strength component, considered factors as a force in the commercial shipping management in Jayapura port, including the following: (1) As the capital city of Papua province, Jayapura Port has an important role in the ship visits flow, therefore commercial shipping operating from the western part of Indonesia to Jayapura and the surrounding area also has an important role; (2) The Commercial Shipping existence certainly has an important role for the Jayapura city which is a strategic area from the interests of defense and state security point of view and economic interests; (3) Jayapura Port, especially its Commercial Shipping section, has an impact on the transportation network structure system in general in Papua Province has evolved along with the Special Autonomy implementation for Papua, in the Papua Province transportation illustrates the integration of the transportation sub-system; (4) The density and busyness level of the port as a commercial pioneer in Jayapura port; (5) The port manager knowledge regarding regulations for the operation of commercial ships; (6) The types of port manager knowledge and suitable and permissible vessel types for commercial services; (7) Manager's knowledge of the cargo ship types.

Meanwhile, the weakness components are following: (1) Incompatibility between the ship visits flow and cargo; (2) Facilities and infrastructure do not support port activities as a commercial shipping center; (3) The commercial shipping routes in the Jayapura Port has not been able to serve maximally according to the community and the region needs; (4) Lack of integration between the Jayapura port as the main port to the development commercial ports; (5) Need for loading and unloading equipment; (6) Freight loading and unloading services; (7) Lack of attention from authorized institutions/ stakeholders to support the commercial shipping effectiveness; (7) Incompatibility between ship types and numbers entering and leaving; (8) The Apo jetty for commercial shipping has developed cracks as the building is 58 years old and has a narrow area of $346.5 \mathrm{~m} 2$ area while the access road is damaged.

External analysis is also carried out on components from outside, namely opportunities, and threats from the development plan for managing the commercial shipping. The opportunities can be indicated as follows: (1) The central and regional government's plans to develop a center activity based on the natural resource potential and leading cultivation activities as the regional economy main drivers; therefore, the commercial port as a supporter of the Jayapura port is very important as a transportation integration; (2) The government's plan to improve the services and infrastructure to support the economic activities since the Jayapura Regency and City includes the national strategic area; (3) Papua with Jayapura capital city entered into the acceleration and Indonesian development (MP3EI) expansion; (4) Protected function area of Papua Province covering: Protected forest areas, nature reserves, wildlife reserves, mangrove forested coastal areas, national park areas, disaster-prone areas, and so on. The functioning cultivation areas in West Papua Province include production forest areas, agricultural areas, fisheries areas, mining areas, industrial estates, tourism areas; (5) The hinterland regional development; (6) Port facilities development such as passenger terminals.

In addition, to the existing opportunities, the commercial shipping management as an effort to develop commercial shipping facilities also includes factors as the following threats: (1) The visitors and passenger's density during the loading and unloading process which hinders the port effectiveness; (2) Time incompatibility needed for the loading and unloading process; (3) Supporting facilities such as forklifts cannot operate to the maximum and passenger terminals and warehouses existence and transit space (embarkation or debarkation); (4) The ships queuing accumulation number for loading and unloading processes; (5) Port buildings collapse due to excess mass load conditions compared to the building age. Based on our research, the complete strategy on the SWOT Matrix is shown in the IFAS and EFAS Table 1. 
Table 1. SWOT Analysis According IFAS and EFAS Matrix

\begin{tabular}{|c|c|c|c|c|}
\hline No & Internal Factors & Item Weight & Rating & Score \\
\hline \multicolumn{5}{|c|}{ Strength } \\
\hline 1 & $\begin{array}{l}\text { As the capital city center of the Papua province, } \\
\text { Jayapura Port and commercial shipping have an } \\
\text { important role. }\end{array}$ & 0.07 & 4 & 0.28 \\
\hline 2 & $\begin{array}{l}\text { Jayapura city is a strategic area from the interest } \\
\text { point of view of national defense and security and the } \\
\text { economic interests. }\end{array}$ & 0.07 & 4 & 0.28 \\
\hline 3 & $\begin{array}{l}\text { Commercial shipping is part of the transportation } \\
\text { sub-system integration. }\end{array}$ & 0.06 & 4 & 0.24 \\
\hline 4 & Density and busyness level of commercial shipping. & 0.07 & 4 & 0.21 \\
\hline 5 & $\begin{array}{l}\text { Port manager knowledge regarding the operation } \\
\text { regulations of commercial ships. }\end{array}$ & 0.06 & 3 & 0.18 \\
\hline 6 & $\begin{array}{l}\text { Types of Port manager knowledge and suitable and } \\
\text { permissible vessels types for commercial services. }\end{array}$ & 0.07 & 3 & 0.21 \\
\hline 7 & Knowledge management about the cargo ship type. & 0.07 & 3 & 0.21 \\
\hline Tot & Score & & & 1.61 \\
\hline \multicolumn{5}{|c|}{ Opportunity } \\
\hline No & External Factors & Item Weight & Rating & Score \\
\hline 1 & $\begin{array}{l}\text { The central and regional governments plan to } \\
\text { develop a center for activities based on the natural } \\
\text { resource potential }\end{array}$ & 0.10 & 4 & 0.4 \\
\hline 2 & $\begin{array}{l}\text { The government plan to improve the infrastructure } \\
\text { and facilities to support the economic activities }\end{array}$ & 0.10 & 4 & 0.4 \\
\hline 3 & $\begin{array}{l}\text { Papua with Jayapura as the capital entered into } \\
\text { (MP3EI). }\end{array}$ & 0.08 & 4 & 0.32 \\
\hline 4 & $\begin{array}{l}\text { Papua Province has a functioning area, production } \\
\text { forest area, agricultural area, fishery area, mining } \\
\text { area, industrial area, tourism area. }\end{array}$ & 0.09 & 4 & 0.36 \\
\hline 5 & The development hinterland region. & 0.08 & 3 & 0.27 \\
\hline 6 & $\begin{array}{l}\text { Port facilities development such as passenger } \\
\text { terminals. }\end{array}$ & 0.09 & 3 & 0.27 \\
\hline Tot & Score & & & 2.0 \\
\hline \multicolumn{5}{|c|}{ Threat } \\
\hline No & External Factors & Item Weight & Rating & Score \\
\hline 1 & $\begin{array}{l}\text { The visitors and passenger's density during the } \\
\text { loading and unloading process which hinders the } \\
\text { port effectiveness. }\end{array}$ & 0.09 & 1 & 0.10 \\
\hline 2 & $\begin{array}{l}\text { Time incompatibility needed for the loading and } \\
\text { unloading process. }\end{array}$ & 0.09 & 1 & 0.09 \\
\hline 3 & $\begin{array}{l}\text { Supporting facilities such as forklifts cannot } \\
\text { maximum operate and the passenger terminals and } \\
\text { warehouses existence also transit space (embarkation/ } \\
\text { debarkation). }\end{array}$ & 0.10 & 1 & 0.10 \\
\hline 4 & $\begin{array}{l}\text { Ships queuing accumulation number for loading and } \\
\text { unloading processes. }\end{array}$ & 0.09 & 1 & 0.09 \\
\hline 5 & $\begin{array}{l}\text { The port building collapse due to the excess mass } \\
\text { load condition compared to the old building }\end{array}$ & 0.09 & 2 & 0.18 \\
\hline Tot & Score & & & 0.56 \\
\hline \multicolumn{5}{|c|}{ Weakness } \\
\hline No & External Factors & Item Weight & Rating & Score \\
\hline
\end{tabular}




\begin{tabular}{|c|c|c|c|c|}
\hline 1 & Mismatch between the ship flow visits and cargo & 0.06 & 2 & 0.12 \\
\hline 2 & $\begin{array}{l}\text { Facilities and infrastructure do not support port } \\
\text { activities as commercial shipping }\end{array}$ & 0.05 & 1 & 0.05 \\
\hline 3 & $\begin{array}{l}\text { The commercial shipping routes in Jayapura Port has } \\
\text { not been able to serve the maximum according to the } \\
\text { community and the region needs. }\end{array}$ & 0.05 & 2 & 0.10 \\
\hline 4 & $\begin{array}{l}\text { Lack of integration between the port of Jayapura as } \\
\text { the main port to the commercial port's development. }\end{array}$ & 0.06 & 2 & 0.12 \\
\hline 5 & The need for loading and unloading tools & 0.07 & 1 & 0.07 \\
\hline 6 & Freight loading and unloading services & 0.05 & 1 & 0.05 \\
\hline 7 & $\begin{array}{l}\text { Lack of attention from the need of authorized } \\
\text { institutions / stakeholders to support the effectiveness } \\
\text { of commercial shipping }\end{array}$ & 0.05 & 2 & 0.10 \\
\hline 8 & $\begin{array}{l}\text { Incompatibility between the number and ships } \\
\text { entering and leaving types. }\end{array}$ & 0.05 & 2 & 0.10 \\
\hline 9 & $\begin{array}{l}\text { Commercial shipping has a cracked building } \\
\text { condition with age of around } 58 \text { years and road } \\
\text { narrow coupled damaged access, only } 346.5 \mathrm{~m}^{2} \text { area. }\end{array}$ & 0.07 & 1 & 0.07 \\
\hline \multicolumn{3}{|c|}{ Total Score } & & 0.56 \\
\hline
\end{tabular}

Source: Research Analysis, 2018.

Based on the total value of IFAS (0.83) and EFAS (1.44) matrix scores can be mapped a SWOT (space matric) in the form of an analysis diagram. This diagram can find out the position of the commercial shipping management strategy in the Jayapura port. By identifying the strategic position based on the matrix space analysis and its description in vector lines, the mapping results the strategy position can be seen in the following figure:

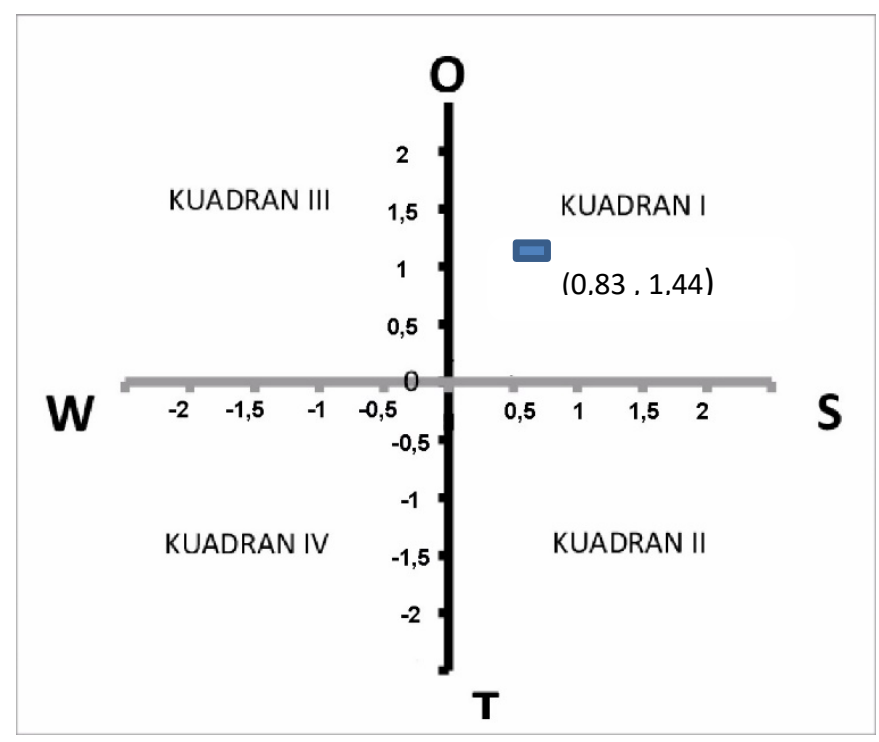

Figure 1. SWOT Analysis Diagram

Source: Research Analysis, 2018.

The SWOT analysis diagram (Figure 1) shows that the strategy is suitable to be used in the commercial shipping management policies analysis in the Jayapura port is the strength-opportunity strategy. The SO strategy strengthens the commercial shipping function as a support for the economic activity centers development and government supporters in MP3EI, commercial port facilities and infrastructure development in order to support all port activities and efficiency, hinterland areas development to maximize busy and crowded commercial shipping functions. 
Government Regulation No. 20, 2010 concerning shipping defines commercial shipping as transportation services in waters on routes established by the government to service areas or regions which are not served by water transportation since they have not provided the commercial benefits. The commercial sea transportation implementation is intended to serve the sea transportation services needs for isolated and lagging areas, provide affordable water transportation services, maintain the Republic of Indonesia sovereignty with commercial ships stop in difficult to reach the border areas. Pioneer sea transportation aims to encourage regional development, increase and even dynamic economic growth distribution and national stability.

The implementation of commercial sea transportation services, facing various obstacles, such as geography, demographics, natural resources, human resources, port infrastructure and facilities in particular availability, infrastructure, and facilities for general development (Balitbang Perhubungan 2007). The lack of port infrastructure and facilities resulting in ship loading and unloading services delays have an impact on shipbuilding, Integration in the commercial sea transportation services implementation is still weak, thus affecting the lack of the objectives achievement of commercial sea transportation; The commercial sea transportation services performance is still low, as a result of effective operational aspects lack and commercial sea transportation services (Indri 2017). The condition at Apo dock as a commercial shipping in the of Jayapura port also experienced these conditions, even worse with the very old dock building condition established since 1960. The commercial shipping sea transportation services still had an impact on the striking price disparity between western Indonesia and the East regions of Indonesia.

Revitalizing the Apo Dock as a commercial shipping is necessary to support the sea highway program. The national sea highway program is the government concrete part in overcoming price inequality of goods and services in terms logistics, especially the logistics distribution from western Indonesia to Eastern Indonesia has made the logistics system in Indonesia quite expensive. The sea highway launch has increasingly raised enormous hopes for the government's commitment to realize Indonesia as the world's maritime axis (Kadarisman et al. 2016).

Commercial shipping as a bridge serves goods distribution from the main sea toll port to the isolated areas in Jayapura. Thus, commercial shipping has a large impact on achieving the sea highway objectives program. The strategy can be applied in revitalizing the Apo dock use the Strength Component strategy, strengthening the commercial shipping function as a support for the economic activity centers development and government supporters in MP3EI by developing commercial port facilities and infrastructure to support all port activities and efficiency. Since the facilities and infrastructure are the keys to a more efficient Apo dock realization.

\section{Conclusion}

The Apo Dock weaknesses as Commercial Shipping in the Jayapura Port are related to the discrepancies problem between the ship flow visits and loading and unloading, the infrastructure and facilities problems within the port, the age problem of the port building. The SWOT analysis results show the Jayapura port Commercial performance was in position I with a position (0.83; 1.44). The strategy used by Commercial Shipping in Jayapura port to develop commercial shipping to be more efficient according to its function was the SO (strength-opportunity) strategy using the advantages exists possessed and the potential of its implementation and able to cover up the existing weaknesses.

\section{References}

Badan Perencanaan Pembangunan Nasional (Bapennas). 2015. Pengembangan Tol Laut dalam RPJMN 2015-2019 dan Implementasi. 2015. Accessed May 1, 2018, https:/www.bappenas.go.id/files/Pengembangan\%20Tol\%20Laut\%20Dalam\%20RPJMN\% 202015-2019\%20Dan\%20Implementasi\%202015.pdf. 
Balitbang Perhubungan. 2007. "Study of the Need for Medium-Term Pioneer Sea Transportation Networks in Efforts to Encourage Other Sectors the Growth”. Jakarta.

Indri, Astiwi F. 2017. "The Requirements of Additional Pioneers Vessel in Banyuwangi Area". Transportation Research News. 29 (2): 303-316.

Kadarisman M, Yuliantini, and Majid SA. 2016. "Sea Transportation System Policy Formulation". Transportation \& Logistics Management Journal 3 (2): 161-183.

Menteri Perhubungan Republik Indonesia. "Peraturan Menteri Perhubungan Republik Indonesia Nomor PM 114 Tahun 2017 Tentang Perubahan Ketiga Atas Peraturan Menteri Perhubungan Nomor PM 10 Tahun 2016 Tentang Tarif Angkutan Barang di Laut dalam Rangka Pelaksanaan Kewajiban Pelayanan Publik (Public Service Obligation)". Accessed June 2, 2018. http://jdih.dephub.go.id/assets/uudocs/permen/2017/PM_114_TAHUN_2017.pdf.

Menteri Perhubungan Republik Indonesia. "Peraturan Menteri Perhubungan Republik Indonesia Nomor PM 38 Tahun 2018 Tentang Perubahan Kedua atas Peraturan Menteri Perhubungan Nomor PM 71 Tahun 2013 Tentang Salvage dan/atau Pekerjaan Bawah Air”. Accessed May 3, 2018. http://Jdih.Dephub.Go.Id/Assets/Uudocs/Permen/2018/Pm_38_Tahun_2018.Pdf

Nainggolan, Poltak Partogi. 2015. "Kebijakan Poros Maritim Dunia Joko Widodo dan Implikasi Internasionalnya”, Jurnal Politica 6, no. 2. https://doi.org/10.22212/jp.v6i2.312.

Peraturan Pemerintah Number 59. 1991. "Pengalihan Bentuk Perusahaan Umum (Perum) Pelabuhan IV menjadi Perusahaan Perseroan (Persero)". Accessed January 1, 2018. https://peraturan.bkpm.go.id/jdih/userfiles/batang/pp_59_1991.pdf .

Peraturan Pemerintah Republik Indonesia (PPRI), "Peraturan Pemerintah Republik Indonesia Nomor 22 Tahun 2011 Tentang Perubahan atas Peraturan Pemerintah Nomor 20 Tahun 2010 Tentang Angkutan di Perairan”. Accessed January 18, 2018. http://ditjenpp.kemenkumham.go.id/arsip/ln/2011/pp22-2011.pdf.

Rutz, Werner OA and James R Coull. 1996. "Inter-island passenger shipping in Indonesia: development of the system: Present characteristics and future requirements". Journal of Transport Geography 4, no. 4, December 1996, 275-286, https://doi.org/10.1016/S09666923(96)00028-2.

Saragi, Frenky Kristian, Desi Albert Mamahit, and Tri Yoga Budi Prasetyo. 2018. "Implementasi Pembangunan Tol Laut untuk Mewujudkan Indonesia sebagai Poros Maritim Dunia, Jurnal Keamanan Maritim 4, no. 1. http://jurnalprodi.idu.ac.id/index.php/KM/article/view/397.

Subandono, Diposaptono . 2017. Membangun Poros Maritim Dunia dalam Perspektif Tata Ruang Laut. Jakarta: Kementerian Kelautan dan Perikanan.

Triatmodjo, B. 2010. Port Planning. Beta Offset. Yogyakarta.

UNCLOS (United Nations Convention on the Law of the Sea) 1982 Article 46. Accessed May 1, 2018. https://www.un.org/depts/los/convention_agreements/texts/unclos/unclos_e.pdf.

Wang, K A. 2007. "SWOT Analysis Process View, The 51st Annual Meeting of the International Society for the Systems Sciences". Tokyo. 